\title{
Uterine Cervix Metastasis as an Initial Manifestation of Metastatic Renal Cell Carcinoma: A Case Report and Review of Literature
}

\author{
Muhannad AlArifi ${ }^{1}$, Khalid Riaz ${ }^{2}$, Mutahir Ali Tunio ${ }^{2^{*}}$ and Mushabbab Al Asiri ${ }^{3}$
}

${ }^{1}$ Muhannad AlArifi, King Saud bin AbdulAziz University for Health Sciences, Riyadh 11345, Saudi Arabia

${ }^{2}$ Khalid Riaz, Radiation Oncology, Comprehensive Cancer Centre, King Fahad Medical City (KFMC), Riyadh 59046, Saudi Arabia

${ }^{3}$ Mushabbab Al Asiri, Director Comprehensive Cancer Center, Chairman Radiation Oncology, King Fahad Medical City, Riyadh-59046, Saudi Arabia

\begin{abstract}
Background: Renal cell carcinoma (RCC) has unpredictable and diverse behaviour. The classic triad of hematuria, loin pain and abdominal mass is uncommon at time of presentation. About $25 \%-30 \%$ of patients are found to have metastases at the time of diagnosis. Bones, lungs, liver and brain are the frequent sites of metastases. $\mathrm{RCC}$ with metastasis to the cervix uteri is rarest manifestation and only four case reports have been published so far.

Case Presentation: Herein we present a case of 70 year old Saudi female presenting with 4 months history of vaginal bleeding and weight loss. Her past medical history revealed left sided radical nephroectomy for RCC. She had no other co-morbidities. On physical examination, she was found emaciated and per vaginal examination showed fragile fungating mass of cervix. The punch biopsy of cervical mass confirmed the diagnosis of metastatic RCC. Further, staging workup showed bilateral pulmonary metastasis. She was given palliative Radiotherapy 30 Gy in 10 fractions followed by Sunitinib $50 \mathrm{mg}$ oral daily, but patient died of progressive disease 4 months of palliative radiotherapy.

Conclusion: Metastatic RCC to cervix uteri is very rare manifestation. The physicians should consider metastasis from another primary as the differential diagnosis in order to plan optimal treatment. Reported treatment is radical hysterectomy with bilateral salpingo-oophorectomy followed by Tyrosine Kinase Inhibitors (TKIs). Patients who are not candidate for surgery; radiotherapy and TKIs is a reasonable option.
\end{abstract}

Keywords: Renal cell carcinoma; Metastasis; Cervix uteri; Rare manifestation

\section{Introduction}

Renal cell carcinoma (RCC) has unpredictable and diverse behavior. The incidence of RCC over last 20 years has progressively increased due to widespread use of modern imaging [1]. About 30\%-50\% of patients are found to have metastases at diagnosis. While bone, lymph nodes, lungs and brain constitute expected 'homing' sites, metastasis may turn up at the unusual locations (skin, testis, maxillary antrum and tongue) [2-4].

Cervix Uteri is rare site of metastasis from other primaries, because of dense stroma and less vascularity. Metastatic RCC to cervix uteri is extremely rare and usually associated with left sided RCC; only four case reports have been published so far [5-8]. The exact mechanism is not known; however retrograde venous flow of tumor cells from left renal vein to the left ovarian vein and cervical and vaginal venous plexus explains the spread of left sided RCC to cervix uteri [9].

Here we present a case of postmenopausal lady with cervix uteri metastasis as initial metastatic manifestation of RCC.

\section{Case Presentation}

A 70 year old Saudi female presented in our clinic with vaginal bleeding and significant weight loss. She had noticed vaginal bleeding for 4 months and it had been rapidly progressing over 2 weeks. Her previous surgical history revealed left sided radical nephrectomy four years back for RCC (Figure 1).

On physical examination, her vitals were stable. She was found severely malnourished and emaciated. There was no palpable lymphadenopathy and examination of chest, heart, nervous system and abdomen was normal. Per vaginal examination showed a fragile easily bleeding fungating lesion of size $5 \times 5 \mathrm{~cm}$ in exo-cervix with involvement of vaginal fornices and right parametrium.

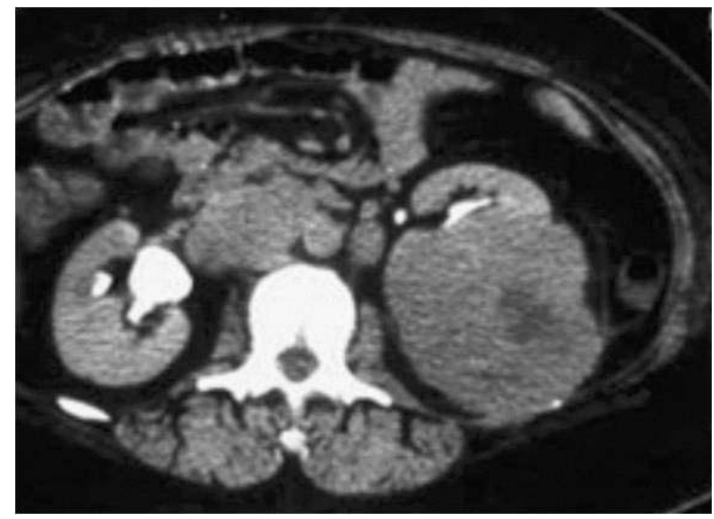

Figure 1: Computed tomography (CT) of abdomen showing mass in left kidney for which radical nephrectomy was performed four years back.

*Corresponding author: Mutahir Tunio, Assistant Consultant, Radiation Oncology, Comprehensive Cancer Centre, King Fahad Medical City (KFMC), Riyadh 59046, Saudi Arabia, Tel: +966 1 2889999; Fax: 9661 4614006; E-mail: drmutahirtonio@hotmail.com

Received June 23, 2012; Accepted July 17, 2012; Published July 20, 2012

Citation: AIArifi M, Riaz K, Tunio MA, Asiri MA. (2012) Uterine Cervix Metastasis as an Initial Manifestation of Metastatic Renal Cell Carcinoma: A Case Report and Review of Literature. J Nucl Med Radiat Ther S6:011. doi:10.4172/2155-9619.S6-011

Copyright: ( 2012 AlArifi M, et al. This is an open-access article distributed under the terms of the Creative Commons Attribution License, which permits unrestricted use, distribution, and reproduction in any medium, provided the original author and source are credited. 
Citation: AlArifi M, Riaz K, Tunio MA, Asiri MA. (2012) Uterine Cervix Metastasis as an Initial Manifestation of Metastatic Renal Cell Carcinoma: A Case Report and Review of Literature. J Nucl Med Radiat Ther S6:011. doi:10.4172/2155-9619.S6-011

Page 2 of 3

Magnetic resonance imaging (MRI) of pelvis showed necrotic mass of cervix uteri mass of size $6 \times 5.5 \mathrm{~cm}$ with bilateral parametrial invasion and no pelvic lymphadenopathy (Figure 2). Computed tomography (CT) abdomen showed absent left kidney consistent with left radical nephrectomy for RCC with no recurrence in the renal bed and CT chest revealed bilateral pulmonary metastasis (Figure 3). Serum chemistry, hematology and bone scan were found normal.

Punch biopsy of mass of cervix uteri was performed, which revealed clear cell histology consistent with metastatic RCC (Figure 4).

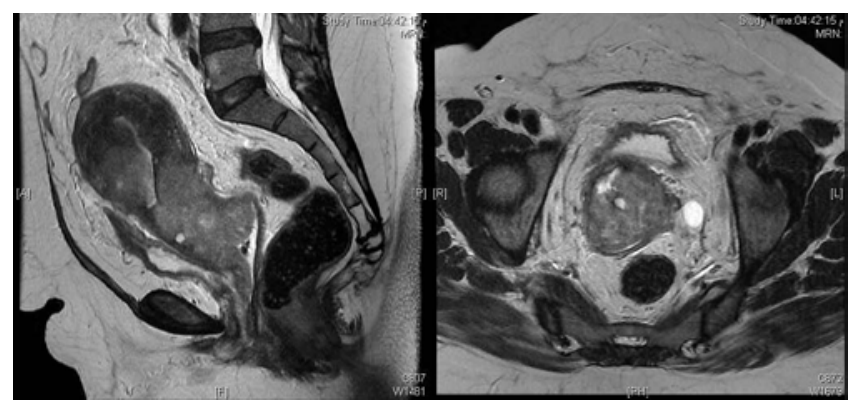

Figure 2: Magnetic resonance imaging (MRI) of pelvis showing $5 \times 5 \mathrm{~m}$ cervical mass with parametrial invasion.
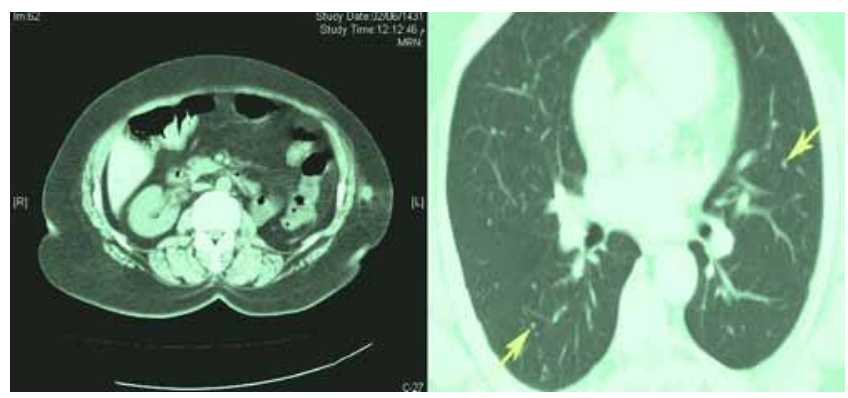

Figure 3: Computed tomography (CT) of (a) abdomen showing left nephrectomy renal bed with no recurrence and (b) chest showing pulmonary metastasis.

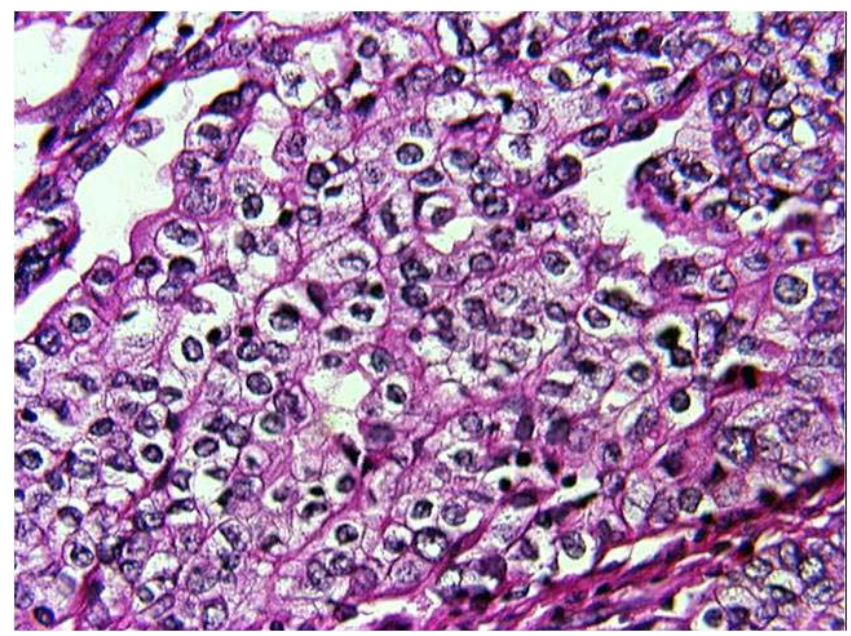

Figure 4: Histopathology of cervical mass showing clear cell consistent with renal cell carcinoma.

\begin{tabular}{|l|l|l|l|}
\hline Author & $\begin{array}{l}\text { Age and } \\
\text { presenting } \\
\text { complaints }\end{array}$ & Treatment offered & Survival \\
\hline $\begin{array}{l}\text { Seseke F, et } \\
\text { al. [5] }\end{array}$ & $\begin{array}{l}\text { Postmenopausal } \\
\text { Vaginal bleeding }\end{array}$ & $\begin{array}{l}\text { Total abdominal hysterectomy and } \\
\text { bilateral salpingo-oophorectomy }\end{array}$ & NA \\
\hline $\begin{array}{l}\text { Bozaci EA, et } \\
\text { al. [6] }\end{array}$ & $\begin{array}{l}19 \text { years } \\
\text { Vaginal bleeding }\end{array}$ & $\begin{array}{l}\text { Total abdominal hysterectomy and } \\
\text { bilateral salpingo-oophorectomy }\end{array}$ & NA \\
\hline $\begin{array}{l}\text { Zafrakas M, } \\
\text { et al. [7] }\end{array}$ & $\begin{array}{l}\text { Vagears } \\
\text { Vaginal bleeding }\end{array}$ & $\begin{array}{l}\text { Total abdominal hysterectomy and } \\
\text { bilateral salpingo-oophorectomy } \\
\text { and pelvic lymph node dissection } \\
\text { And Sunitinib 50 mg oral daily }\end{array}$ & NA \\
\hline $\begin{array}{l}\text { Godfrey GJ, } \\
\text { et al. [8] }\end{array}$ & $\begin{array}{l}\text { Postmenopausal } \\
\text { lady }\end{array}$ & $\begin{array}{l}\text { Total abdominal hysterectomy and } \\
\text { bilateral salpingo-oophorectomy }\end{array}$ & NA \\
\hline Our case & $\begin{array}{l}70 \text { years } \\
\text { Vaginal bleeding } \\
\text { and weight loss }\end{array}$ & $\begin{array}{l}\text { Palliative radiotherapy and } \\
\text { Sunitinib 50 mg oral daily }\end{array}$ & 4 months \\
\hline
\end{tabular}

Table 1: Previously published case reports on Renal Cell Carcinoma metastasizing to cervix uteri.

After presenting this case in a multidisciplinary tumor (MDT) meeting, patient was given external beam radiation therapy (EBRT) 30 Grays (Gy) in 10 fractions to cervix uteri mass to control per vaginal bleeding. Post radiation therapy, her vaginal bleeding was much controlled and she was sent to medical oncology team and patient was started on sunitinib $50 \mathrm{mg}$ oral daily. Patient died of progressive pulmonary disease 4 months of palliative EBRT.

\section{Discussion}

Relatively few case reports of primary extra-pelvic carcinomas with metastasis to cervix uteri have been published. The most frequent primary carcinomas metastasizing to uterus and cervix are the breast, stomach, ovarian and colorectal cancers [10].

Renal Cell carcinoma (RCC) may remain clinically occult for the most of its course and the tumor in the kidney may progress unnoticed to a large mass until metastases appear. About two third of cases of RCC metastasize to lungs, liver and bones. Only less than $0.5 \%$ cases metastasize to female genital system [9]. Uterine cervix metastasis as an initial manifestation of metastatic RCC is extremely rare and only four cases have been published so far Table 1. All case reported had left sided RCC, which explains the possible route of spread of renal tumor cells via retrograde venous flow from left renal vein, left ovarian vein and then cervical venous plexus [7]. The treatment of choice for uterine cervix metastasis is the surgical excision in form of total abdominal hysterectomy and bilateral salpingo-oophorectomy (TAH+BSO) with or without lymph node dissection followed by TKIs such Sunitinib, Sorafenib and Temsirolimus.

Our patient was not surgical candidate because of extensive lung metastases. We achieved good haemostatic control of vaginal bleeding by palliative radiotherapy. Prognosis of uterine cervix metastasis depends on presence of metachronous metastasis as our patient died within four months of treatment secondary to lung metastasis.

\section{Conclusion}

Metastatic RCC to cervix uteri is very rare manifestation. The physicians should consider metastasis from another primary as the differential diagnosis in order to plan optimal treatment. Reported treatment is TAH+BSO followed by TKIs. Patients who are not candidates for surgery; radiotherapy and TKIs are a reasonable option. 
Citation: AlArifi M, Riaz K, Tunio MA, Asiri MA. (2012) Uterine Cervix Metastasis as an Initial Manifestation of Metastatic Renal Cell Carcinoma: A Case Report and Review of Literature. J Nucl Med Radiat Ther S6:011. doi:10.4172/2155-9619.S6-011

\section{References}

1. Tunio MA, Hashmi A, Rafi M (2010) Need for a new trial to evaluate postoperative radiotherapy in renal cell carcinoma: A meta-analysis of randomized controlled trials. Ann Oncol 21: 1839-1845.

2. Tunio MA, Hashmi A, Rafi M (2009) Epistaxis and proptosis -Unusual primary manifestations of metastatic renal cell carcinoma. Pak J Med Sci 25: 10121014.

3. Tunio MA, Hashmi A, Rafi M (2009) Renal cell carcinoma with initial presentation as erythematous skin metastasis. Isra Medical Journal 1: 79-81.

4. Tunio MA, AlAsiri M, Ahmad S, Fareed M , Bayoumi Y (2012) Tongue metastasis as an initial manifestation of metastasis in renal cell carcinoma: A case report. J Solid Tumors 2: 39-42.

5. Seseke F, Kugler A, Hemmerlein B, Gross AJ, Ringert RH, et al. (1998) Metastasis from renal cell carcinoma to the cervix uteri. Scand J Urol Nephrol 32: $290-292$
6. Bozaci EA, Atabekoğlu C, Sertçelik A, Unlü C, Ortaç F (2005) Metachronous metastases from renal cell carcinoma to uterine cervix and vagina: case report and review of literature. Gynecol Oncol 99: 232-235.

7. Zafrakas M, Papanikolaou AN, Venizelos ID, Kellartzis D, Agorastos T, et al. (2009) A rare case of renal cell carcinoma metastasizing to the uterine cervix. Eur J Gynaecol Oncol 30: 239-40.

8. Godfrey GJ, Moore G, Alatassi H (2010) Presentation of renal cell carcinoma as cervical polyp metastasis. J Low Genit Tract Dis 14: 387-389.

9. Modi PR, John PJ, Joshi DP, Rohit NJ (2004) Vaginal metastasis from renal cell carcinoma - a case report. Indian J Urol 20: 169-170.

10. Pérez-Montiel D, Serrano-Olvera A, Salazar LC, Cetina-Pérez L, Candelaria $M$, et al. (2012) Adenocarcinoma metastatic to uterine cervix: a case series. J Obstet Gynaecol Res 38: 541-549.

This article was originally published in a special issue, Cancer Radiation Therapy handled by Editor(s). Dr. XinChen, University of Arkansas for Medical Sciences, USA 